\title{
Folic acid uptake by the human syncytiotrophoblast is affected by gestational diabetes, hyperleptinemia, and TNF- $\alpha$
}

\author{
João R. Araújo', Ana Correia-Branco', Liliana Moreira', Carla Ramalho², Fátima Martel' and Elisa Keating'
}

BACKGROUND: The mechanisms whereby gestational diabetes mellitus (GDM) increases the risk of fetal overgrowth and development of metabolic diseases later in life are likely to involve changes in nutrient supply to the fetus. Hence, in this work, we hypothesize that GDM may affect folic acid (FA) supply to the placenta and fetus.

METHODS: We compared ${ }^{3} \mathrm{H}-\mathrm{FA}$ uptake by human cytotrophoblasts isolated from normal pregnancies (normal trophoblasts; NTB cells) and GDM pregnancies (diabetic trophoblasts; DTB cells) and investigated the effect of GDM hallmarks on ${ }^{3} \mathrm{H}$-FA uptake by BeWo cells.

RESULTS: ${ }^{3} \mathrm{H}$-FA uptake by NTB and DTB cells was time dependent and acidic $\mathrm{pH}$ stimulated. When compared with NTB, ${ }^{3} \mathrm{H}-\mathrm{FA}$ uptake by DTB cells was more sensitive to acidic $\mathrm{pH}$ changes and to 5-methyltetrahydrofolate and pemetrexed (PTX) inhibition, indicating a proportionally greater involvement of the proton-coupled folate transporter (PCFT). A 4-h exposure of BeWo cells to lipopolysaccharide (LPS, 1-10 $\mu \mathrm{g} / \mathrm{ml})$ or to high levels of tumor necrosis factor- $\alpha$ (TNF- $\alpha, 300 \mathrm{ng} / \mathrm{l})$ significantly reduced ${ }^{3} \mathrm{H}$-FA uptake. Moreover, hyperleptinemic conditions (100 ng/ml leptin) decreased ${ }^{3} \mathrm{H}$-FA uptake by BeWo cells in a time-dependent manner when compared with normoleptinemic conditions (1 $\mathrm{ng} / \mathrm{ml}$ leptin).

CONCLUSION: GDM modulates ${ }^{3} \mathrm{H}$-FA uptake by the syncytiotrophoblast, and leptin as well as TNF- $\alpha$ downregulate it.

$\mathbf{T}$ he nutritionally essential folic acid (FA; vitamin $\left.\mathrm{B}_{9}\right)$ is the parent structure and oxidized form of the folate family of compounds. These compounds facilitate the intracellular transfer of one-carbon units, being involved in the synthesis of purine and pyrimidine precursors of nucleic acids, the metabolism of several amino acids, and the initiation of protein synthesis in the mitochondria (1). Maternal-to-fetal transport of folates at the level of the syncytiotrophoblast epithelium is crucial for placental and fetal development and growth because neither the placenta nor the fetus can synthesize this vitamin. In fact, maternal folate deficiency has been associated with low birth weight and neural tube defects (2), and supplementation with FA during the periconceptional period reduces the incidence of such outcomes $(2,3)$.

The human placenta expresses the reduced folate carrier (RFC1) (4), the folate receptor isoforms $\alpha$ (5) and $\beta$ (6), and the proton-coupled folate transporter (PCFT) (7). These transporters are believed to act coordinately to ensure the vectorial transfer of folate from maternal-to-fetal circulation.

Gestational diabetes mellitus (GDM), defined as a degree of glucose intolerance with onset or first recognition during pregnancy, affects about $7 \%$ of all pregnancies (8). This condition is associated with fetal macrosomia, which increases the risk of perinatal complications, and with cardiovascular and metabolic diseases later in life both in the mother (9) and in the offspring (10). The mechanisms whereby GDM increases the risk of fetal overgrowth and development of metabolic diseases later in life are still unclear, but are likely to involve changes in nutrient supply to the fetus (11). Methyl-nutrients such as folates, vitamin $B_{12}$, and methionine enable cellular methylation reactions and thus epigenetic regulation of gene expression. As such, we herein hypothesize that GDM may specifically affect folate supply to the placenta and the fetus.

To test our hypothesis, we characterized FA uptake by primary cultured cytotrophoblasts isolated from human placentas of GDM-affected pregnancies (DTB cells) and compared it with FA uptake by cytotrophoblasts isolated from human placentas of uncomplicated pregnancies (NTB cells).

Hyperglycemia, hyperinsulinemia, and insulin resistance are the hallmarks of GDM. Hyperleptinemia (12) and increased inflammation (13) are also associated with this disease. Therefore, we also investigated the modulation of FA placental uptake by these GDM-associated conditions.

We verified that ${ }^{3} \mathrm{H}$-FA uptake by DTB cells was more $\mathrm{pH}$ dependent at acidic $\mathrm{pH}$ compared with NTB cells, indicating a higher PCFT:RFC1 ratio activity in these cells. We also observed that hyperleptinemia and tumor necrosis factor- $\alpha$ $(\mathrm{TNF}-\alpha)$ reduced FA uptake by BeWo cells.

\section{RESULTS}

Clinical, Anthropometric, and Demographic Characteristics of the Study Groups

As shown in Table 1 (14), control and GDM groups were closely matched in terms of clinical, anthropometric, and demographic data. A trend toward increased birth weight and length and placental weight was observed in the GDM group, but these differences did not reach statistical significance. 
Table 1. Clinical, anthropometric, and demographic data of the study groups

\begin{tabular}{|c|c|c|}
\hline & Controls & GDM \\
\hline \multicolumn{3}{|l|}{ Mothers } \\
\hline$n$ & 11 & 7 \\
\hline Maternal age $(y)$ & $32.4 \pm 1.7$ & $33.4 \pm 1.5$ \\
\hline BMI before delivery $\left(\mathrm{kg} / \mathrm{m}^{2}\right)^{\mathrm{a}}$ & $31.2 \pm 2.1$ & $32.3 \pm 1.1$ \\
\hline Gravida $(n)$ & $2.5 \pm 0.5$ & $2.1 \pm 0.3$ \\
\hline Parity $(n)$ & $1.1 \pm 0.3$ & $1.0 \pm 0.2$ \\
\hline \multicolumn{3}{|l|}{ Mode of delivery } \\
\hline Vaginal ( $n(\%))$ & $4(36)$ & $3(43)$ \\
\hline Cesarean $(n(\%))$ & $7(64)$ & $4(57)$ \\
\hline Therapeutics of GDM ( $n(\%))$ & - & $\begin{array}{l}\text { Nutritional: } 4 \text { (57); } \\
\text { insulin: } 3 \text { (42) }\end{array}$ \\
\hline Fasting blood glucose $\left(\mathrm{mmol} / \mathrm{l}^{\mathrm{b}}\right.$ & $4.3 \pm 0.1$ & $4.5 \pm 0.2$ \\
\hline $\mathrm{HbA}_{1 \mathrm{C}}(\%)^{\mathrm{c}}$ & - & $5.3 \pm 0.1$ \\
\hline Periconceptional FA use $(n(\%))^{\mathrm{d}}$ & $10(91)^{\mathrm{e}}$ & $4(57)^{f}$ \\
\hline Smokers $(n(\%))$ & $0(0)^{g}$ & $0(0)$ \\
\hline \multicolumn{3}{|l|}{ Infants } \\
\hline Gestational age at birth $(w k)^{h}$ & $39.2 \pm 0.3$ & $39.3 \pm 0.3$ \\
\hline Birth weight $(g)^{i}$ & $3,198.6 \pm 122.6$ & $3,362.9 \pm 176.3$ \\
\hline Birth length $(\mathrm{cm})^{j}$ & $47.9 \pm 0.4$ & $49.4 \pm 0.7$ \\
\hline Placental weight (g) & $590.6 \pm 25.8$ & $648.4 \pm 37.6$ \\
\hline SGA newborn ( $n(\%))$ & SGA 1(9) & SGA $0(0)$ \\
\hline AGA newborn $(n(\%))$ & AGA 9 (82) & AGA $6(86)$ \\
\hline LGA newborn $(n(\%))$ & LGA 1 (9) & LGA 1 (14) \\
\hline \multicolumn{3}{|l|}{ Gender ( $n(\%))$} \\
\hline Male & $3(27)$ & $3(43)$ \\
\hline Female & $8(73)$ & $4-(57)$ \\
\hline 5-min Apgar score & $9.1 \pm 0.2$ & $9.0 \pm 0.2$ \\
\hline
\end{tabular}

Values represent means \pm SEM.

aParameter unknown for two subjects (one from each group). bValues obtained at 24-28 wk of gestation. Parameter unknown for three subjects from the control group. values obtained at 35-36 wk of gestation. Parameter unknown for the subjects from control group because this assay is not typically ordered for subjects with no history of glucose mismanagement. ${ }^{d}$ Dosage and initiation period unknown. ${ }^{\text {eParameter }}$ unknown for one subject. Parameter unknown for three subjects. ${ }^{9}$ Parameter unknown for one subject. ${ }^{h}$ Gestational age: number of completed weeks at the time of delivery, determined by prenatal ultrasound at 11-13 wk. 'Birth weight was evaluated to the nearest gram. 'Length was evaluated to the nearest tenth of a centimeter after birth. AGA, adequate for gestational age; FA, folic acid; GDM, gestational diabetic mellitus; LGA, large for gestational age, classified according to published references standards (14); SGA, small for gestational age.

${ }^{3} \mathrm{H}-\mathrm{FA}$ Apical Uptake by NTB and DTB Cells Is Time and $\mathrm{pH}$ Dependent

To determine the time course of accumulation of ${ }^{3} \mathrm{H}-\mathrm{FA}$ in NTB and DTB cells, cells were incubated at pH 5.5 with $20 \mathrm{nmol} / \mathrm{l}$ ${ }^{3} \mathrm{H}-\mathrm{FA}$ for various periods of time. As shown in Figure 1, both NTB and DTB cells accumulate ${ }^{3} \mathrm{H}-\mathrm{FA}$ in a time-dependent manner. In DTB cells, the rates of both inward and outward transport ( $k_{\text {in }}$ and $k_{\text {out }}$, respectively) were significantly higher than those for NTB cells, but the accumulation at steady state $\left(A_{\max }\right)$ was unaltered (Table 2$)$.

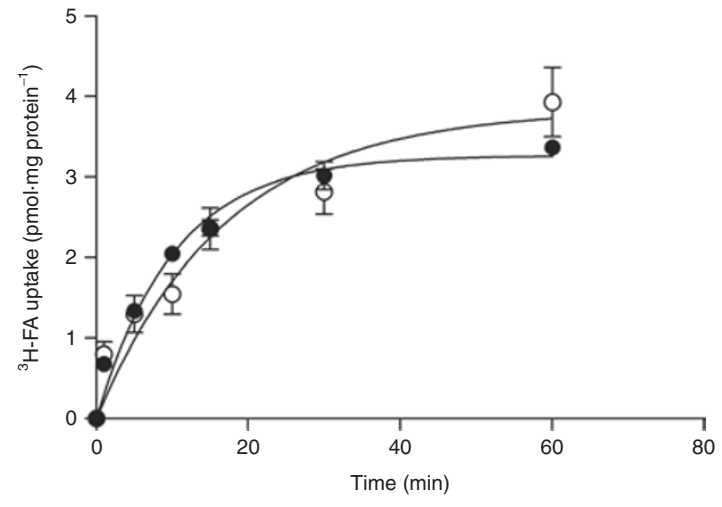

Figure 1. Time-course of ${ }^{3} \mathrm{H}-\mathrm{FA}$ apical uptake by NTB (open circles) and DTB (solid circles) cells. Cells were incubated at $\mathrm{pH} 5.5$ with $20 \mathrm{nmol} / \mathrm{I}^{3} \mathrm{H}-\mathrm{FA}$ for various periods of time ( $n=6-8$, from three or four distinct placentas). Values shown are arithmetic means \pm SEM. DTB, diabetic trophoblasts; FA, folic acid; NTB, normal trophoblasts.

Apical uptake of ${ }^{3} \mathrm{H}-\mathrm{FA}$ by NTB cells was linear with time for up to $6 \mathrm{~min}$ of incubation. Therefore, a 6-min incubation time was selected for subsequent experiments.

The effect of extracellular $\mathrm{pH}$ on the uptake of ${ }^{3} \mathrm{H}-\mathrm{FA}$ was examined by varying the $\mathrm{pH}$ of the extracellular media from 5.0 to 8.0 (Figure 2). ${ }^{3} \mathrm{H}$-FA uptake in both NTB and DTB cells was found to be markedly acidic-pH stimulated. Strikingly, $\mathrm{pH}$-dependence was greater in DTB cells, particularly for acidic $\mathrm{pH}$ values (5.0-6.0).

Uptake was also found to be saturable in both NTB and DTB cells but there were no differences in the evaluated kinetic parameters, maximal velocity $\left(V_{\max }\right)$, and Michaelis constant $\left(K_{\mathrm{m}}\right)$ (data not shown).

\section{${ }^{3} \mathrm{H}$-FA Uptake by NTB and DTB Cells Is Differentially Modulated by} Folate Analogs and by SITS

To compare the specificity of the carrier process involved in ${ }^{3} \mathrm{H}$-FA uptake in NTB and DTB cells, we determined the effect of an excess concentration of FA and its structural analogs 5-methyltetrahydrofolate, methotrexate (amethopterin), and pemetrexed (PTX) and of 4-acetamido-4'-isothiocyanato2,2'-stilbenedisulfonic acid disodium salt hydrate (SITS; an anion transport inhibitor) and thiamine pyrophosphate (TPP, a known inhibitor of RFC1) upon the uptake of ${ }^{3} \mathrm{H}$-FA by NTB and DTB cells at pH 5.5 (Figure 3). Most of these compounds were able to similarly reduce ${ }^{3} \mathrm{H}-\mathrm{FA}$ uptake in NTB and DTB cells. The exceptions were SITS, which slightly inhibited uptake by $12 \%$ in NTB but not in DTB cells; 5-methyltetrahydrofolate and PTX, which caused a greater inhibition of ${ }^{3} \mathrm{H}$ FA uptake in DTB cells; and TPP, which was devoid of effect in NTB and DTB cells.

\section{Hyperleptinemia and Inflammatory Markers Modulate ${ }^{3} \mathrm{H}-\mathrm{FA}$ Uptake by BeWo Cells}

The next set of experiments aimed to investigate the effect of specific GDM molecular hallmarks on ${ }^{3} \mathrm{H}-\mathrm{FA}$ uptake by placental cells. For this purpose, we investigated the short- (1 and $4 \mathrm{~h})$ and long-term $(24 \mathrm{~h})$ effects of increasing concentrations of 
Table 2. Time-course parameters of ${ }^{3} \mathrm{H}-\mathrm{FA}$ uptake by NTB and DTB cells

\begin{tabular}{|c|c|c|c|c|c|c|c|}
\hline & $n$ & $A_{\max }\left(\mathrm{pmol} \cdot \mathrm{mg}\right.$ protein $\left.^{-1}\right)$ & $P$ & $k_{\text {in }}\left(\mathrm{pmol} \cdot \mathrm{mg}\right.$ protein $\left.{ }^{-1} \cdot \mathrm{min}^{-1}\right)$ & $P$ & $k_{\text {out }}\left(\min ^{-1}\right)$ & $P$ \\
\hline NTB & 8 & $3.84 \pm 0.34$ & & $0.23 \pm 0.03$ & & $0.059 \pm 0.012$ & 0.033 \\
\hline DTB & 6 & $3.27 \pm 0.10$ & NS & $0.32 \pm 0.02$ & 0.039 & $0.097 \pm 0.009$ & \\
\hline
\end{tabular}

Cells were incubated at $\mathrm{pH} 5.5$ with $20 \mathrm{nmol} / \mathrm{I}^{3} \mathrm{H}$-FA for various periods of time ( $n=6-8$, from 3 to 4 distinct placentas). Values represent means $\pm \mathrm{SEM}$. $A_{\text {max }}$ accumulation at steady state; DTB, diabetic trophoblasts; FA, folic acid; $k_{\text {in' }}$ constant for inward transport; $k_{\text {out' }}$ constant for outward transport; NS, not significant; NTB, normal trophoblasts.

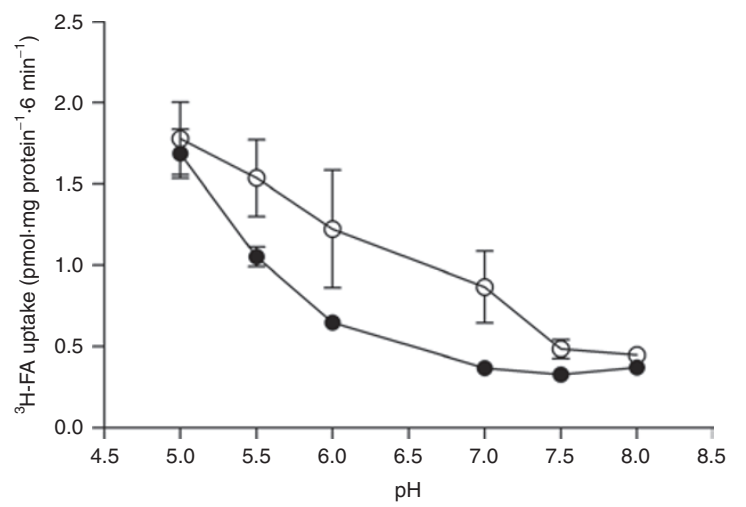

Figure 2. $\mathrm{pH}$-dependence of ${ }^{3} \mathrm{H}-\mathrm{FA}$ apical uptake by NTB (open circles) and DTB (solid circles) cells. Initial rates of uptake were determined in cells incubated with $20 \mathrm{nmol} / /{ }^{3} \mathrm{H}-\mathrm{FA}$ for $6 \mathrm{~min}$ at extracellular $\mathrm{pH}$ ranging from 5.0 to 8.0. Values shown are arithmetic means \pm SEM $(n=4-8$, from two to three distinct placentas). Two-way ANOVA retrieved significance values for the $\mathrm{pH}(P<0.0001)$ and the GDM $(P=0.0026)$ effects. FA, folic acid; GDM, gestational diabetes mellitus.

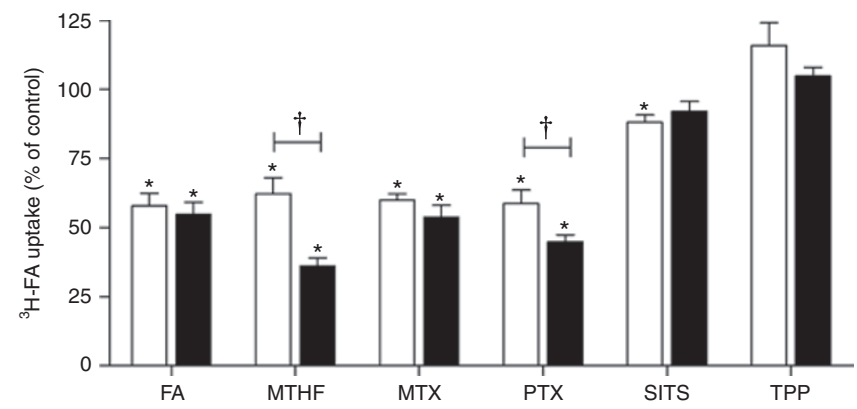

Figure 3. Effect of folic acid (FA; $100 \mu \mathrm{mol} / \mathrm{l})$, 5-methyltetrahydrofolate (MTHF; $10 \mu \mathrm{mol} / \mathrm{I})$, methotrexate (MTX; $10 \mu \mathrm{mol} / \mathrm{I})$, pemetrexed (PTX; $20 \mu \mathrm{mol} / \mathrm{l})$, 4-acetamido-4'-isothiocyanato-2,2'-stilbenedisulfonic acid disodium salt hydrate (SITS; $500 \mu \mathrm{mol} / \mathrm{I})$, and thiamine pyrophosphate (TPP; $100 \mu \mathrm{mol} / \mathrm{I}$ ) on ${ }^{3} \mathrm{H}-\mathrm{FA}$ apical uptake by NTB (white bars) and DTB (black bars) cells. Cells were incubated with $20 \mathrm{nmol} /{ }^{3} \mathrm{H}$-FA for $6 \mathrm{~min}$ at $\mathrm{pH} 5.5$ in the presence of the compound ( $n=6-11$, from 2 to 4 distinct placentas) or the respective solvent (control; $n=5-13)$. Values shown are arithmetic means \pm SEM. ${ }^{*}$ Significantly different from control $(P<0.05)$; ${ }^{\dagger}$ significantly different from NTB cells $(P<0.05)$.

D-glucose, insulin, leptin, lipopolysaccharide (LPS), and TNF- $\alpha$ on the uptake of ${ }^{3} \mathrm{H}$-FA by BeWo cells at physiological $\mathrm{pH}$.

Hyperglycemia (10 and $30 \mathrm{mmol} / \mathrm{l} \mathrm{D}$-glucose (8)) and hyperinsulinemia (50 and $100 \mathrm{nmol} / \mathrm{l}$ insulin (15)) were devoid of effect on ${ }^{3} \mathrm{H}$-FA uptake by BeWo cells compared with isosmotic normoglycemic $(5.6 \mathrm{mmol} / \mathrm{l}$ glucose) and normoinsulinemic (10 pmol/l insulin (16)) conditions (Figure 4a,b).

On the other hand, as shown in Figure 4c, $100 \mathrm{ng} / \mathrm{ml}$ leptin (experimental hyperleptinemia (15), corresponding to $\sim 3$ times the plasma levels of leptin found in women with GDM) decreased ${ }^{3} \mathrm{H}$-FA uptake by BeWo cells up to $25 \%$ in a time-dependent manner compared with leptin $1 \mathrm{ng} / \mathrm{ml}$ (which is in the range of concentrations found in normal pregnancies (17)). Curiously, a 4-h exposure of BeWo cells to 1, 100,300, or 1,000 ng/ml leptin increased ${ }^{3} \mathrm{H}$-FA uptake to $121.9 \pm 4.7 \% ; 114.3 \pm 3.7 \%$; $109.5 \pm$ $2.8 \%$; or $119.8 \pm 8.6 \%$, respectively $(n=11)$ compared with uptake in the total absence of this hormone.

Finally, a 4-h exposure of BeWo cells to 1 or $10 \mu \mathrm{g} / \mathrm{ml}$ LPS concentrations known to induce proinflammatory cytokine (interleukin-6 and TNF- $\alpha$ ) secretion in trophoblast cells (18) and to $300 \mathrm{ng} / \mathrm{l}$ TNF- $\alpha$ itself significantly reduced ${ }^{3} \mathrm{H}-$ FA uptake (Figure $4 \mathrm{~d})$. Smaller $(1 \mathrm{~h})$ or longer $(24 \mathrm{~h})$ periods of exposure to these proinflammatory conditions (data not shown) or to lower concentrations of TNF- $\alpha$ (Figure 4d) did not alter ${ }^{3} \mathrm{H}$-FA transport.

We next tested the effect of selected GDM conditions on the kinetic parameters of ${ }^{3} \mathrm{H}-\mathrm{FA}$ uptake in BeWo cells. A 4-h and a 24-h treatment with 1 and $100 \mathrm{ng} / \mathrm{ml} \mathrm{leptin,} \mathrm{respectively,} \mathrm{and} \mathrm{a}$ 4-h treatment with $10 \mu \mathrm{g} / \mathrm{ml}$ LPS did not alter the $K_{\mathrm{m}}$ and $V_{\max }$ of ${ }^{3} \mathrm{H}$-FA uptake by this cell line (data not shown).

Hyperleptinemia-Induced Inhibition of ${ }^{3} \mathrm{H}-\mathrm{FA}$ Uptake Is Independent of Signaling through JAK/STAT, PI3K, PKA, PKC, and MAPK

The functions attributed to leptin depend on its binding to OB-R leptin receptors, which have been localized in the human syncytiotrophoblast (19), resulting in activation of the following signal transduction pathways: janus kinases (JAK)/signal transducers and activators of transcription (STAT), phosphoinositide 3-kinase (PI3K), protein kinases (PK) A and C and mitogen-activated protein kinases (MAPK) (extracellularsignal-regulated-kinase (ERK), c-Jun $\mathrm{N}$-terminal kinase (JNK), and p38 MAPK) (20).

Thus, we investigated the signaling mechanisms involved in the inhibitory effect mediated by leptin on ${ }^{3} \mathrm{H}$-FA uptake by BeWo cells by assessing the effect of exposing BeWo cells for $24 \mathrm{~h}$ to inhibitors of intracellular signaling pathways, to leptin, or to both.

The role of JAK2/STAT3 in leptin $(100 \mathrm{ng} / \mathrm{ml})$-induced inhibition of ${ }^{3} \mathrm{H}$-FA uptake was investigated by treating BeWo cells for $24 \mathrm{~h}$ with $5 \mu \mathrm{mol} / \mathrm{l}$ of the well-established JAK2 inhibitor AG490 (21). Of note, the inhibitory effect of leptin on the uptake of ${ }^{3} \mathrm{H}-\mathrm{FA}$ in the presence of AG490 was smaller than the inhibitory effect of leptin alone (Figure 5). However, western blotting phosphorylation assays failed to confirm the involvement of JAK2/STAT3 signaling in the leptin effect in BeWo cells (data not shown). 
a

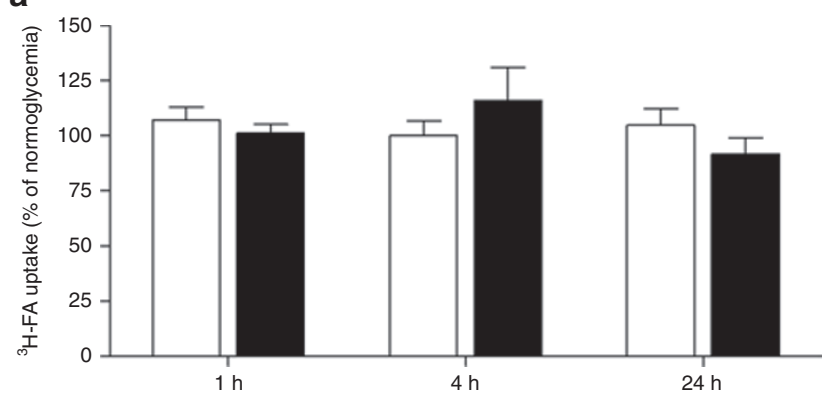

b

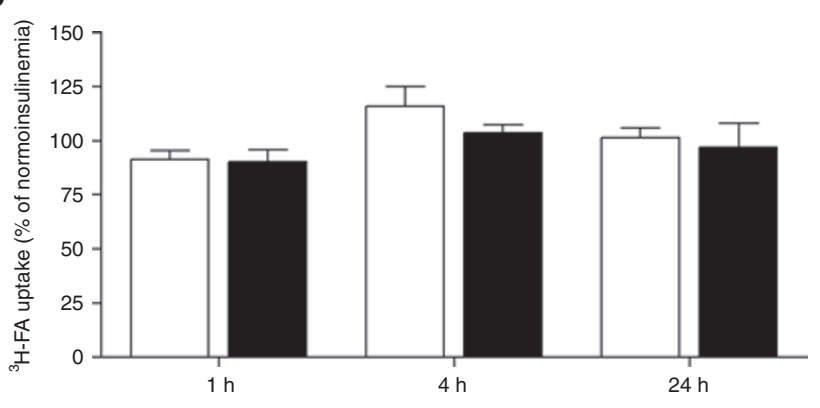

C

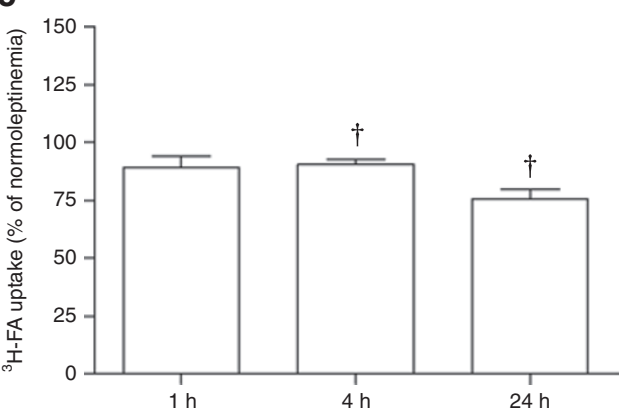

d

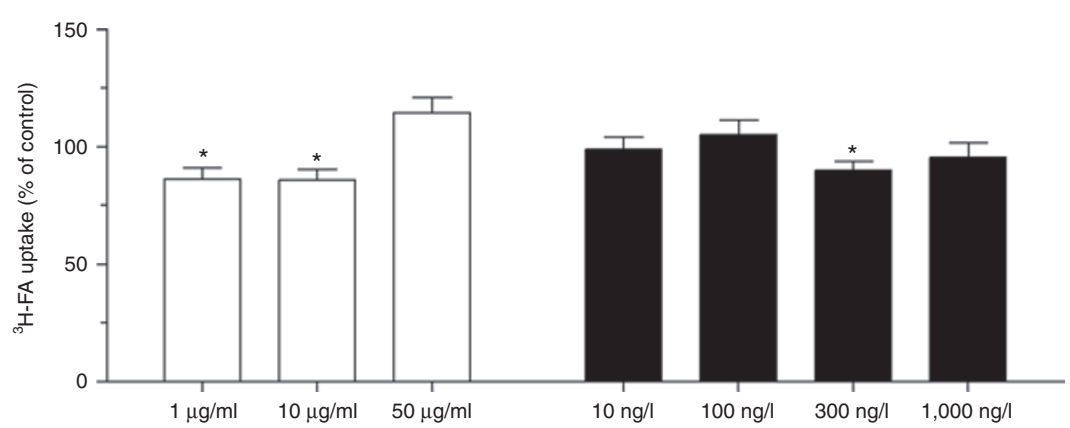

Figure 4. Effect of GDM-associated conditions on ${ }^{3} \mathrm{H}$-FA apical uptake by BeWo cells. Cells were exposed to (a) D-glucose at 10 or $30 \mathrm{mmol} / \mathrm{l}$ (white and black bars respectively; $n=8-9$ ) or $5.6 \mathrm{mmol} / \mathrm{l}$ (supplemented with mannitol up to 10 or $30 \mathrm{mmol} / \mathrm{l}$ for isosmotic control, corresponding to normoglycemia (100\%), $n=9$ ) for the indicated periods of time; (b) insulin at 1 or $50 \mathrm{nmol} / \mathrm{l}$ (white and black bars respectively; $n=8-12$ ) or at $0.01 \mathrm{nmol} / \mathrm{l}$ (normoinsulinemia (100\%), $n=9-12$ ) for the indicated periods of time; (c) leptin at $100 \mathrm{ng} / \mathrm{ml}$ (white bars; $n=8-10)$ or $1 \mathrm{ng} / \mathrm{ml}$ (normoleptinemia (100\%), $n=9-11$ ) for the indicated periods of time; and (d) LPS $1-50 \mu \mathrm{g} / \mathrm{ml}$ (white bars $n=12-17$ ), tumor necrosis factor- $\alpha$ at $10-1,000 \mathrm{ng} / \mathrm{l}$ (black bars; $n=$ $10-11)$, or the respective solvents (control $(100 \%) ; n=11-14$ ) for $4 \mathrm{~h}$. Initial rates of uptake were determined in cells incubated with $50 \mathrm{nmol} / \mathrm{I}^{3} \mathrm{H}-\mathrm{FA}$ for $6 \mathrm{~min}$ at $\mathrm{pH}$ 7.5. Values shown are arithmetic means \pm SEM. ${ }^{*}$ Significantly different from control $(P<0.05)$; ${ }^{\dagger}$ Significantly different from normoleptinemia $(P<0.05)$. FA, folic acid; GDM, gestational diabetes mellitus; LPS, lipopolysaccharide.

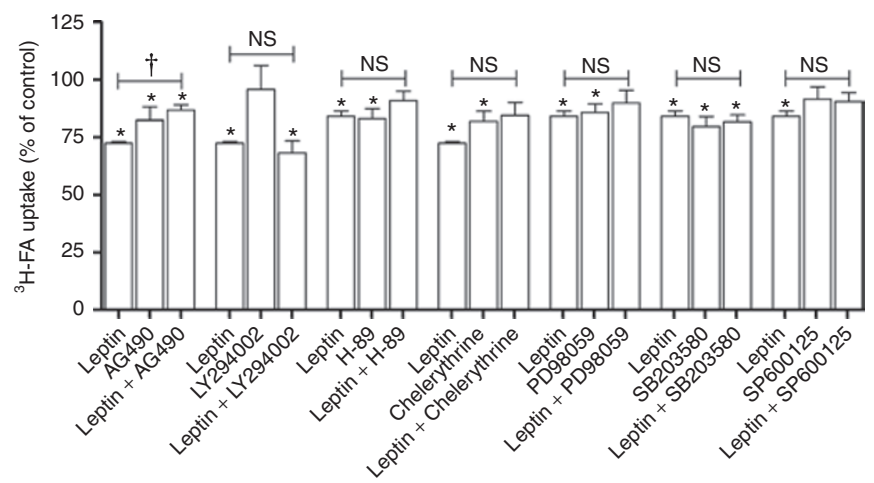

Figure 5. Effect of inhibitors of signaling pathways on the apical uptake of ${ }^{3} \mathrm{H}-\mathrm{FA}$ and on leptin-induced inhibition of ${ }^{3} \mathrm{H}$-FA uptake by BeWo cells. Initial rates of uptake were determined in cells incubated for $6 \mathrm{~min}$ with $50 \mathrm{nmol} / \mathrm{I}{ }^{3} \mathrm{H}-\mathrm{FA}$ after treatment for $24 \mathrm{~h}$ with $100 \mathrm{ng} / \mathrm{ml}$ leptin, $5 \mu \mathrm{mol} / \mathrm{l}$

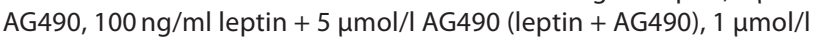
LY294002, $100 \mathrm{ng} / \mathrm{ml} \mathrm{leptin} \mathrm{+} 1 \mu \mathrm{mol} / \mathrm{l} \mathrm{LY} 294002$ (leptin + LY294002), $1 \mu \mathrm{mol} / \mathrm{l} \mathrm{H}-89,100 \mathrm{ng} / \mathrm{ml} \mathrm{leptin}+1 \mu \mathrm{mol} / \mathrm{l} \mathrm{H}-89$ (leptin + H-89), 0.1 $\mu \mathrm{mol} / \mathrm{l}$ chelerythrine, $100 \mathrm{ng} / \mathrm{ml}$ leptin $+0.1 \mu \mathrm{mol} / \mathrm{l}$ chelerythrine (leptin + chelerythrine), $2.5 \mu \mathrm{mol} / / \mathrm{PD} 98059,100 \mathrm{ng} / \mathrm{ml}$ leptin $+2.5 \mu \mathrm{mol} / \mathrm{I}$ PD98059 (leptin + PD98059), $9.6 \mu \mathrm{mol} / \mathrm{l} \mathrm{SB203580,100} \mathrm{ng/ml} \mathrm{leptin} \mathrm{+}$ $9.6 \mu \mathrm{mol} / \mathrm{I} \mathrm{SB203580}$ (leptin + SB203580), 5 umol/l SP600125, and $100 \mathrm{ng} / \mathrm{ml}$ leptin $+5 \mu \mathrm{mol} / \mathrm{I} \mathrm{SP} 600125($ leptin + SP600125) $(n=6-11)$. Values shown are arithmetic means \pm SEM. ${ }^{*}$ Significantly different from control $(P<0.05)$; ${ }^{\dagger}$ significantly different from leptin $(P<0.05)$. FA, folic acid; NS, not significant.
With respect to the PI3K pathway, LY29400 (1 $\mu \mathrm{mol} / \mathrm{l})$, a specific inhibitor of PI3K activity (22), was not able to alter ${ }^{3} \mathrm{H}-\mathrm{FA}$ uptake by itself and it did not affect the inhibitory effect of leptin on ${ }^{3} \mathrm{H}$-FA uptake, indicating that PI3K signaling is not involved in ${ }^{3} \mathrm{H}$-FA baseline uptake or in the leptin effect on this process (Figure 5).

H-89 (23) $(1 \mu \mathrm{mol} / \mathrm{l})$ and chelerythrine (24) $(0.1 \mu \mathrm{mol} / \mathrm{l})$, two specific inhibitors of PKA and PKC, respectively, reduced ${ }^{3} \mathrm{H}-\mathrm{FA}$ uptake (by $17-18 \%$ ), indicating that PKA and PKC activation is required for the baseline transport of this vitamin (Figure 5). However, the inhibitory effect of leptin on ${ }^{3} \mathrm{H}-\mathrm{FA}$ uptake was not affected by either, excluding the involvement of PKA and PKC on the leptin inhibitory effect on ${ }^{3} \mathrm{H}$-FA uptake by BeWo cells.

Finally, the involvement of MAPK pathways was investigated by testing the effect of specific inhibitors of MAPK/ ERK kinase (MEK) (25) (PD980592.5 $\mu \mathrm{mol} / \mathrm{l})$, p38 MAPK (26) (SB2035809.6 $\mu \mathrm{mol} / \mathrm{l})$, and c-Jun $\mathrm{N}$-terminal kinase (27) $(\mathrm{SP} 6001255 \mu \mathrm{mol} / \mathrm{l})$. Uptake of ${ }^{3} \mathrm{H}-\mathrm{FA}$ was reduced (by 14-20\%) in the presence of either PD98059 or SB203580 but it was not affected by SP600125. Hence, MEK and p38 MAPK, but not c-Jun N-terminal kinase activation, appear to be required for ${ }^{3} \mathrm{H}-\mathrm{FA}$ baseline transport into BeWo cells (Figure 5). Moreover, the inhibitory effect of leptin on ${ }^{3} \mathrm{H}-\mathrm{FA}$ uptake was not affected by either of these compounds, thereby 
excluding the involvement of the MAPK pathway in the inhibitory effect of leptin.

\section{DISCUSSION}

It is currently accepted that GDM precipitates offsprings' risk for developing cardiometabolic complications later in life $(10,28)$. However, the exact molecular mechanisms underlying this programming effect are still unknown. One speculative explanation is that the intrauterine environment during GDM, perturbed by conditions such as hyperglycemia, hyperinsulinemia or even hyperleptinemia, and increased inflammatory environment, may induce epigenetic changes that will ultimately influence fetoplacental physiology and developmental programming (29).

Given that folates are obligatory cofactors for the provision of methyl groups for epigenetic regulation of gene expression and that little is known about the influence of GDM on fetoplacental folate homeostasis, the aims of this work were to investigate whether GDM affects FA placental transport and to identify specific GDM molecular hallmarks that may interfere with this process. To do this, we used two different approaches. First, we characterized ${ }^{3} \mathrm{H}$-FA transport in human cytotrophoblasts isolated from normal and GDM pregnancies. Second, we investigated the effect of specific GDM conditions on ${ }^{3} \mathrm{H}-\mathrm{FA}$ uptake in the BeWo cell line, a placental cellular model.

Both NTB and BeWo cells have been shown by us (30-32) and by others (33) to be suitable models for the study of placental transport mechanisms. Indeed, FA uptake characteristics and modulation have been shown to be very similar in both models (34).

When we compared ${ }^{3} \mathrm{H}$-FA transport characteristics in NTB and DTB cells, we found that, although GDM does not significantly change the steady-state intracellular accumulation of ${ }^{3} \mathrm{H}-\mathrm{FA}, \mathrm{DTB}$ cells have higher rates of inward and outward transport, suggesting that a higher turnover of intracellular FA is required in these cells to maintain normal FA homeostasis.

The $\mathrm{pH}$-dependence profiles of ${ }^{3} \mathrm{H}$-FA uptake by NTB and DTB cells revealed an acidic optimum $\mathrm{pH}$, pointing to the functional presence of the high-affinity folate: $\mathrm{H}^{+}$symporter PCFT. In addition, the greater $\mathrm{pH}$-dependence observed in DTB cells for low $\mathrm{pH}$ values may indicate a higher PCFT:RFC1 relative activity in these cells. This finding is confirmed by the greater PTX-induced inhibition of uptake at pH 5.5 in DTB as compared with NTB cells (PTX is a high-affinity PCFT substrate but a very-low-affinity RFC1 substrate (35)).

Taken together, these results suggest that ${ }^{3} \mathrm{H}$-FA uptake by DTB cells is more dependent on PCFT, although quantitatively similar, compared with NTB cells. Similarly, previous results from our group revealed that GDM modulates the interplay of different L-methionine transporters, although it does not quantitatively affect the amino acid transport capacity (data not shown). The strict clinical follow-up of GDM pregnant women may have masked potential functional differences in placental transport capacity of both nutrients.

To reinforce the biological significance of our findings, similar studies could be performed in other placental models such as placental perfusion or syncytiotrophoblast plasma membrane vesicles isolated from normal and GDM pregnancies.

Hyperglycemia, hyperinsulinemia, hyperleptinemia (12), and increased inflammation (13) are associated with GDM. To understand whether these molecular markers alter ${ }^{3} \mathrm{H}-\mathrm{FA}$ placental uptake, we investigated their effects on ${ }^{3} \mathrm{H}$-FA uptake by BeWo cells.

We verified that high concentrations of glucose and insulin did not affect ${ }^{3} \mathrm{H}$-FA uptake. Accordingly, our group had previously demonstrated that ${ }^{3} \mathrm{H}-\mathrm{FA}$ uptake by NTB cells was insensitive to short-term hyperglycemia and to both shortand long-term insulin exposure (32).

Of note, experimental hyperleptinemic conditions were revealed as an inhibitor of ${ }^{3} \mathrm{H}-\mathrm{FA}$ uptake in a time-dependent manner when compared with uptake in the presence of physiological levels of leptin. In addition, high levels of LPS, known to induce proinflammatory cytokine TNF- $\alpha$ secretion in trophoblasts (18), or TNF- $\alpha$ itself inhibited ${ }^{3} \mathrm{H}$-FA uptake by BeWo cells. Curiously, LPS and TNF- $\alpha$ inhibitory effects disappear for the highest concentrations tested. It is possible, as described by Torricelli et al. (18), that in our cell system, the highest concentrations of such proinflammatory stimuli generate a negative feedback loop by the locally inducing anti-inflammatory cytokine production that may attenuate proinflammatorydriven responses, such as inhibition of ${ }^{3} \mathrm{H}$-FA uptake.

To our knowledge, this is the first time that an effect of leptin, LPS, and TNF- $\alpha$ on FA placental transport has been described. These findings support the idea advanced by others that leptin (19), and eventually TNF- $\alpha$ (36), may act as regulators of placental nutrient transport and therefore of fetal growth.

In this respect, Jansson et al. (15) and von Versen-Hoynck et al. (19) demonstrated that leptin increased system A amino acid transporter activity in placental villous fragments. In those works, leptin effect is expressed relative to the absence of the hormone. Of note, when we express the effect of $4 \mathrm{~h}$ leptin relative to the absence of this hormone, we also observe an increase in ${ }^{3} \mathrm{H}$-FA uptake. However, when we express the effect of leptin relative to normal leptin concentrations in pregnancy, which is physiologically more relevant, we observe the above referred time-dependent reduction of ${ }^{3} \mathrm{H}$-FA uptake. These observations indicate that the choice of control conditions for the study of pathology markers should take into account the levels of those markers in the healthy state.

Concerning TNF- $\alpha$ effects on placental nutrient transport, different findings have been reported. High levels of this cytokine have been shown to decrease L-methionine uptake (data not shown) or to increase arachidonic and docosahexaenoic acid uptake (data not shown) or system A activity (36) in human trophoblasts. Altogether, these observations reinforce the idea that TNF- $\alpha$ may well act as a regulator of placental nutrient transport.

The search for intracellular pathways that could be involved in the inhibitory effect of leptin on ${ }^{3} \mathrm{H}-\mathrm{FA}$ uptake by BeWo showed that ${ }^{3} \mathrm{H}$-FA uptake was partially inhibited by JAK2/ STAT3, PKA, PKC, extracellular signal-regulated kinase/ mitogen-activated protein kinase kinase, and p38 MAPK 
pharmacological inhibition. Accordingly, folate transport in rat intestinal cells had already been described to be under the control of PKA, PKC (37).

In addition, pharmacological assays indicated a partial reversion of the leptin effect by the presence of AG490 (an inhibitor of JAK2 (21)), an effect that was not confirmed by western blotting assays. The failure in activation of JAK2/STAT3 signaling cascade by leptin had already been previously observed in BeWo cells by Caüzac et al. (38) who proposed that this pathway is not functional in this placental cell model.

The lack of involvement of PI3K and MAPK on leptin effect is in agreement with the lack of effect of insulin because PI3K and the MAPK phosphorylation cascades are in the cross talk of both leptin and insulin stimulation of placental cells (39).

In conclusion, our work demonstrates that GDM modulates ${ }^{3} \mathrm{H}$-FA uptake by placental cells and that leptin, as well as TNF- $\alpha$, downregulate it.

These conclusions are particularly interesting if we consider that leptin has early emerged as an important player in fetal programming (40) and may lead to the speculation that this programming effect could be related to leptin's observed effect on folate placental homeostasis.

\section{METHODS}

\section{Materials}

In this study, we used ${ }^{3} \mathrm{H}-\mathrm{FA}\left(\left[3,5,7,9-{ }^{3} \mathrm{H}\right]\right.$-FA sodium salt; specific activity 40.0 $\mathrm{Ci} \mathrm{mmol}^{-1}$ ) (American Radiolabeled Chemicals, St. Louis, MO); 5-methyltetrahydrofolate disodium salt, amethopterin, chelerythrine chloride, Dulbecco's modified Eagle's medium, FA, H-89 dihydrochloride hydrate, Ham's F12K medium (Kaighn's modification), human recombinant insulin, human recombinant TNF- $\alpha$, LPS from Escherichia coli 0111:B4, LY294002 hydrochloride, PD98059, SITS, SP600125, TPP, and tyrphostin AG490 (Sigma, St. Louis, MO); human recombinant leptin (Invitrogen, Carlsbad, CA); PTX (Eli Lilly, Indianapolis, IN); and SB203580 (Alomone Labs, Jerusalem, Israel).

\section{Collection of Human Placentas}

Collection and processing of human placentas were approved by the Ethics Committee for Health of C.H.S. João, Porto. Human placentas were obtained, with informed consent, at the Department of Obstetrics and Gynecology of C.H.S. João from uncomplicated or GDM term pregnancies (37-41 wk) within half an hour after spontaneous delivery or elective cesarean section. Control placentas represented normal pregnancies with no associated maternal or fetal pathology and were collected at random.

In pregnant women without prior known diabetes, the diagnosis of GDM was performed using a two-step approach. All pregnant women were tested by a $50-\mathrm{g}$ glucose challenge test at $24-28 \mathrm{wk}$ of gestation. In those with a blood glucose level $\geq 140 \mathrm{mg} / \mathrm{dl}(7.8 \mathrm{mmol} / \mathrm{l})$, $1 \mathrm{~h}$ after the oral glucose load a diagnostic oral glucose tolerance test was performed. GDM was diagnosed according to the criteria defined by Carpenter and Coustan (41). These pregnancies were not associated with any major maternal or fetal pathology in addition to GDM. Women with GDM were treated with diet and exercise therapy up to the time of delivery. Insulin therapy was introduced whenever fasting blood glucose level was $\geq 5 \mathrm{mmol} / 1$ or 2 -h postprandial blood glucose level was $\geq 6.7 \mathrm{mmol} / \mathrm{l}$, despite consistent dietary and exercise adjustments. Clinical, anthropometric, and demographic data for control or GDM groups are given in Table 1.

\section{Primary Culture of Human Cytotrophoblasts}

Villous cytotrophoblasts corresponding to control or GDM pregnancies (NTB and DTB cells, respectively) were isolated using a modification of the technique described by Kliman et al. (42) as previously described by Keating et al. (31). Briefly, tissue was digested in Hank's balanced salt solution containing $0.15 \%$ trypsin (Invitrogen) and $0.02 \%$ DNAse I (Sigma) and the resulting cell suspensions were run in a discontinuous Percoll gradient (Sigma). Then, cytotrophoblast pellets were resuspended in Dulbecco's modified Eagle's medium and seeded on 24-well plastic cell culture clusters $\left(2 \mathrm{~cm}^{2}\right.$; diameter $16 \mathrm{~mm}$; TPP, Trasadingen, Switzerland) at a density of $6-7.5 \times 10^{5} \mathrm{cells} / \mathrm{cm}^{2}$. After $72 \mathrm{~h}$ in culture, cells aggregated to form syncytial clumps corresponding to syncytiotrophoblasts and were used for transport experiments.

\section{BeWo Cell Culture}

The BeWo cell line was obtained from Deutsche Sammlung von Mikroorganismen und Zellkulturen (ACC-458; DMSZ, Braunschweig, Germany) and was used between passage numbers 6 and 29. The cells were cultured as previously described (31).

\section{FA Uptake Studies}

The transport experiments in NTB, DTB, and BeWo cells were performed in buffer with the following composition (in mmol/l): 125 $\mathrm{NaCl}, 4.8 \mathrm{KCl}, 1.2 \mathrm{KH}_{2} \mathrm{PO}_{4}, 12.5$ HEPES-NaOH, 12.5 2-[N-morpholino] ethanesulfonic acid hydrate (Sigma), $1.2 \mathrm{MgSO}_{4}, 1.2 \mathrm{CaCl}_{2}$, and $5.6 \mathrm{mmol} / \mathrm{l} \mathrm{D}(+)$-glucose (Merck, Darmstadt, Germany), $\mathrm{pH} 5.5$ or 7.5 (unless otherwise stated), as previously described (32). ${ }^{3} \mathrm{H}-\mathrm{FA}$ was used in concentrations of 20 or $50 \mathrm{nmol} / 1$ (except in the experiments for determination of the kinetics of ${ }^{3} \mathrm{H}$-FA uptake).

The concentrations of folate analogs of SITS and of TPP used in the characterization of FA uptake were chosen based on previous work from our group $(30,32,43)$ and others $(7,35,44)$.

The total protein content of cell monolayers was determined as described by Bradford (45), and it was not altered by any of the compounds tested, indicating that cell viability was not compromised (data not shown).

\section{Effect of GDM-Associated Hallmarks on ${ }^{3} \mathrm{H}-\mathrm{FA}$ Uptake in BeWo Cells}

The effect of GDM-associated conditions on ${ }^{3} \mathrm{H}$-FA uptake was tested at physiological $\mathrm{pH}$ in 5- to 8-d-old BeWo cell cultures. Cells were exposed to different concentrations of D-glucose, insulin, leptin, LPS or TNF- $\alpha$, or the respective solvent in fetal calf serum-free culture medium for 1,4 , or $24 \mathrm{~h}$. After these treatments, transport experiments were performed as previously described (32). The effect of inhibitors of signaling pathways was tested by cultivating cells, during specific time periods, in fetal calf serum-free medium containing selected GDM markers (which significantly altered ${ }^{3} \mathrm{H}-\mathrm{FA}$ uptake) plus these inhibitors or the respective solvents.

\section{Calculations and Statistics}

For the analysis of the time course of ${ }^{3} \mathrm{H}-\mathrm{FA}$ uptake, the parameters of equation (1) were fitted to the experimental data using a nonlinear regression analysis (46).

$$
A(t)=k_{\text {in }} / k_{\text {out }}\left(1-\mathrm{e}^{-k_{\text {out }} \cdot t}\right)
$$

$A(t)$ represents the accumulation of ${ }^{3} \mathrm{H}$-FA at time $t, k_{\text {in }}$ and $k_{\text {out }}$ are the rate constants for inward and outward transport, respectively, and $t$ is the incubation time. $A_{\text {max }}$ is defined as the accumulation at steady state $(t \rightarrow \infty) \cdot k_{\text {in }}$ is given in pmol.mg protein ${ }^{-1} \cdot \mathrm{min}^{-1}$ and $k_{\text {out }}$ in $\mathrm{min}^{-1}$. Arithmetic means are given with SEM.

For the analysis of the saturation curve of ${ }^{3} \mathrm{H}$-FA uptake, the parameters of the Michaelis-Menten equation were fitted to the experimental data using nonlinear regression analysis (46).

Statistical significance of the difference between various groups was evaluated by one-way or two-way (in the case of $\mathrm{pH}$-dependence) ANOVA test followed by the Bonferroni test. For comparison between two groups, Student's $t$ test was used. Differences were considered significant when $P<0.05$.

The value of $n$ indicates the number of replicates of at least two different experiments or placentas.

\section{ACKNOWLEDGMENTS}

We thank Joana Silva and Paula Soares (Institute of Molecular Pathology and Immunology, University of Porto, Portugal) for the kind donation of the STAT3 and phospho-STAT3 antibodies. 


\section{STATEMENT OF FINANCIAL SUPPORT}

This work was supported by Fundação para a Ciência e Tecnologia (FCT) and Programa Operacional Temático de Fatores de Competitividade (COMPETE), Quadro de Referência Estratégico Nacional (QREN), and Fundo Europeu de Desenvolvimento Regional (FEDER) (PTDC/SAU-OSM/102239/2008; SFRH/ BPD/40170/2007; and SFRH/BD/63086/2009).

\section{REFERENCES}

1. Worthington-Roberts B. Nutrition. In: Cohen W, Cherry S, Merkatz I, eds. Cherry and Merkatz's Complications of Pregnancy. 5th ed. London: Lippincott Williams \& Wilkins, 1999:17-49.

2. Lucock M. Folic acid: nutritional biochemistry, molecular biology, and role in disease processes. Mol Genet Metab 2000;71:121-38.

3. Wilson RD, Johnson JA, Wyatt P, et al.; Genetics Committee of the Society of Obstetricians and Gynaecologists of Canada and The Motherisk Program. Pre-conceptional vitamin/folic acid supplementation 2007: the use of folic acid in combination with a multivitamin supplement for the prevention of neural tube defects and other congenital anomalies. J Obstet Gynaecol Can 2007;29:1003-26.

4. Whetstine JR, Flatley RM, Matherly LH. The human reduced folate carrier gene is ubiquitously and differentially expressed in normal human tissues: identification of seven non-coding exons and characterization of a novel promoter. Biochem J 2002;367(Pt 3):629-40.

5. Antony AC, Utley C, Van Horne KC, Kolhouse JF. Isolation and characterization of a folate receptor from human placenta. J Biol Chem 1981;256:9684-92.

6. Elnakat H, Ratnam M. Distribution, functionality and gene regulation of folate receptor isoforms: implications in targeted therapy. Adv Drug Deliv Rev 2004;56:1067-84.

7. Qiu A, Jansen M, Sakaris A, et al. Identification of an intestinal folate transporter and the molecular basis for hereditary folate malabsorption. Cell 2006;127:917-28.

8. American Diabetes Association. Diagnosis and classification of diabetes mellitus. Diabetes Care 2011;34:S62-9.

9. Crowther CA, Hiller JE, Moss JR, McPhee AJ, Jeffries WS, Robinson JS Australian Carbohydrate Intolerance Study in Pregnant Women (ACHOIS) Trial Group. Effect of treatment of gestational diabetes mellitus on pregnancy outcomes. N Engl J Med 2005;352:2477-86.

10. Gluckman PD, Hanson MA, Cooper C, Thornburg KL. Effect of in utero and early-life conditions on adult health and disease. $\mathrm{N}$ Engl J Med 2008;359:61-73.

11. Heerwagen MJ, Miller MR, Barbour LA, Friedman JE. Maternal obesity and fetal metabolic programming: a fertile epigenetic soil. Am J Physiol Regul Integr Comp Physiol 2010;299:R711-22.

12. Herrera E, Ortega-Senovilla H. Disturbances in lipid metabolism in diabetic pregnancy - Are these the cause of the problem? Best Pract Res Clin Endocrinol Metab 2010;24:515-25.

13. Catalano PM. Obesity, insulin resistance, and pregnancy outcome. Reproduction 2010;140:365-71.

14. Battaglia FC, Lubchenco LO. A practical classification of newborn infant by weight and gestational age. J Pediatr 1967;71:159-63.

15. Jansson N, Greenwood SL, Johansson BR, Powell TL, Jansson T. Leptin stimulates the activity of the system A amino acid transporter in human placental villous fragments. J Clin Endocrinol Metab 2003;88:1205-11.

16. Yachi Y, Tanaka Y, Anasako Y, Nishibata I, Saito K, Sone H. Contribution of first trimester fasting plasma insulin levels to the incidence of glucose intolerance in later pregnancy: Tanaka women's clinic study. Diabetes Res Clin Pract 2011;92:293-8.

17. Lepercq J, Cauzac M, Lahlou N, et al. Overexpression of placental leptin in diabetic pregnancy: a critical role for insulin. Diabetes 1998;47:847-50.

18. Torricelli M, Voltolini C, Bloise E, et al. Urocortin increases IL-4 and IL-10 secretion and reverses LPS-induced TNF-alpha release from human trophoblast primary cells. Am J Reprod Immunol 2009;62:224-31.

19. von Versen-Höynck F, Rajakumar A, Parrott MS, Powers RW. Leptin affects system A amino acid transport activity in the human placenta: evidence for STAT3 dependent mechanisms. Placenta 2009;30:361-7.

20. Frühbeck $G$. Intracellular signalling pathways activated by leptin. Biochem J 2006;393(Pt 1):7-20.

21. Meydan N, Grunberger T, Dadi H, et al. Inhibition of acute lymphoblastic leukaemia by a Jak-2 inhibitor. Nature 1996;379:645-8.
22. Vlahos CJ, Matter WF, Hui KY, Brown RF. A specific inhibitor of phosphatidylinositol 3-kinase, 2-(4-morpholinyl)-8-phenyl-4H-1-benzopyran4-one (LY294002). J Biol Chem 1994;269:5241-8.

23. Lochner A, Moolman JA. The many faces of H89: a review. Cardiovasc Drug Rev 2006;24:261-74.

24. Herbert JM, Augereau JM, Gleye J, Maffrand JP. Chelerythrine is a potent and specific inhibitor of protein kinase C. Biochem Biophys Res Commun 1990;172:993-9.

25. Dudley DT, Pang L, Decker SJ, Bridges AJ, Saltiel AR. A synthetic inhibitor of the mitogen-activated protein kinase cascade. Proc Natl Acad Sci USA 1995;92:7686-9.

26. Kumar S, Jiang MS, Adams JL, Lee JC. Pyridinylimidazole compound SB 203580 inhibits the activity but not the activation of p38 mitogen-activated protein kinase. Biochem Biophys Res Commun 1999;263:825-31.

27. Bennett BL, Sasaki DT, Murray BW, et al. SP600125, an anthrapyrazolone inhibitor of Jun N-terminal kinase. Proc Natl Acad Sci USA 2001;98:136816

28. Boney CM, Verma A, Tucker R, Vohr BR. Metabolic syndrome in childhood: association with birth weight, maternal obesity, and gestational diabetes mellitus. Pediatrics 2005;115:e290-6.

29. Pinney SE, Simmons RA. Metabolic programming, epigenetics, and gestational diabetes mellitus. Curr Diab Rep 2012;12:67-74.

30. Keating E, Lemos C, Azevedo I, Martel F. Comparison of folic acid uptake characteristics by human placental choriocarcinoma cells at acidic and physiological pH. Can J Physiol Pharmacol 2006;84:247-55.

31. Keating E, Gonçalves P, Lemos C, et al. Progesterone inhibits folic acid transport in human trophoblasts. J Membr Biol 2007;216:143-52.

32. Keating E, Gonçalves P, Campos I, Costa F, Martel F. Folic acid uptake by the human syncytiotrophoblast: interference by pharmacotherapy, drugs of abuse and pathological conditions. Reprod Toxicol 2009;28: 511-20.

33. Bloxam DL, Bax CM, Bax BE. Culture of syncytiotrophoblast for the study of human placental transfer. Part I: Isolation and purification of cytotrophoblast. Placenta 1997;18:93-8.

34. Keating E, Martel F. Placental transport of folate and thiamine: a minireview. Curr Womens Health Rev 2008;4:141-6.

35. Zhao R, Qiu A, Tsai E, Jansen M, Akabas MH, Goldman ID. The protoncoupled folate transporter: impact on pemetrexed transport and on antifolates activities compared with the reduced folate carrier. Mol Pharmacol $2008 ; 74: 854-62$

36. Jones HN, Jansson T, Powell TL. IL-6 stimulates system A amino acid transporter activity in trophoblast cells through STAT3 and increased expression of SNAT2. Am J Physiol, Cell Physiol 2009;297:C1228-35.

37. Hamid A, Kaur J. Role of signaling pathways in the regulation of folate transport in ethanol-fed rats. J Nutr Biochem 2009;20:291-7.

38. Caüzac M, Czuba D, Girard J, Hauguel-de Mouzon S. Transduction of leptin growth signals in placental cells is independent of JAK-STAT activation. Placenta 2003;24:378-84.

39. Homko C, Sivan E, Chen X, Reece EA, Boden G. Insulin secretion during and after pregnancy in patients with gestational diabetes mellitus. J Clin Endocrinol Metab 2001;86:568-73.

40. Bouret SG, Draper SJ, Simerly RB. Trophic action of leptin on hypothalamic neurons that regulate feeding. Science 2004;304:108-10.

41. Carpenter MW, Coustan DR. Criteria for screening tests for gestational diabetes. Am J Obstet Gynecol 1982;144:768-73.

42. Kliman HJ, Nestler JE, Sermasi E, Sanger JM, Strauss JF 3rd. Purification, characterization, and in vitro differentiation of cytotrophoblasts from human term placentae. Endocrinology 1986;118:1567-82.

43. Keating E, Lemos C, Azevedo I, Martel F. Characteristics of thiamine uptake by the BeWo human trophoblast cell line. J Biochem Mol Biol 2006;39:383-93.

44. Nakai $\mathrm{Y}$, Inoue $\mathrm{K}$, Abe $\mathrm{N}$, et al. Functional characterization of human proton-coupled folate transporter/heme carrier protein 1 heterologously expressed in mammalian cells as a folate transporter. J Pharmacol Exp Ther 2007;322:469-76.

45. Bradford MM. A rapid and sensitive method for the quantitation of microgram quantities of protein utilizing the principle of protein-dye binding. Anal Biochem 1976;72:248-54.

46. Muzyka A, Tarkani O, Yelizanof V. Non-linear regression (curve fit). GraphPad Prism Software for Windows. San Diego, CA, 2005. 